Agro-Science Journal of Tropical Agriculture, Food, Environment and Extension Volume 15 Number 3 (September 2016) pp. 34 - 40

ISSN 1119-7455

\title{
PEDOGENESIS OF TWO LITHOLOGICALLY SIMILAR SOILS UNDER VEGETATION OF CONTRASTING FEATURES IN OHAJI, SOUTH-EASTERN NIGERIA
}

\author{
Ahukaemere*, C.M., Onweremadu, E.U., Ndukwu, B.N., and Okoli, N.H. \\ Department of Soil Science \& Technology, Federal University of Technology, PMB 1526 Owerri, Nigeria \\ *Corresponding author's email: mildredshine@yahoo.com, henrynek34@gmail.com
}

\begin{abstract}
Knowledge of pedogenic processes in soils is vital in deepening our understanding of soil development. A pedogenic study was carried on two pedons underlain by similar lithologic material, one located under a seven-year-old vegetation and the other under a twenty-three-year-old vegetation. The two contrasting vegetation ages were randomly selected. Samples were taken from the two pedons and subjected to laboratory analyses. The results were then subjected to statistical analysis using the Statistical Analytical System. The results showed that soil profiles were deep $(200 \mathrm{~cm})$ and well drained. The soils were darker and browner in the epipedon and redder down the profile in all the pedons. The soil formed under the 23-year-old vegetation had a thick $(18 \mathrm{~cm}) O$ horizon with $O e$ and Oa components. There was no $O$ horizon found in the soil formed under the 7-year-old vegetation. The dominant pedogenic processes in the two soil groups were littering, melanization, illuviation, eluviation, leaching, mineralization, and humification. The two soils were preponderantly sand. Sand accumulation was higher (> 80\%) in the epipedon when compared to the subsurface horizons $(<70 \%)$. All the soils had silt/clay ratios greater than 0.2. Soils were strongly acidic (4.56-5.01), moderate to high in available phosphorus (17.49-21.47 $\mathrm{mg} \mathrm{kg}{ }^{-1)}$ and low to moderate in organic carbon (8.78-14.49 $\left.\mathrm{g} \mathrm{kg}^{-1}\right)$. Because soil survey reports may not give a clear outlook of the important pedogenic characteristics of soils, the research becomes very necessary in many localities of similar need.
\end{abstract}

Key words: argillation, eluviation, horizon, pedogenesis, vegetation

\section{INTRODUCTION}

Pedogenic characteristics of soils have been a subject of intense debate in pedological studies. These pedogenic characteristics could be influenced strongly by the soil forming factors such as parent materials and organisms (including vegetation), Early pedogenic characteristics of soil may greatly be influenced by the chemical and mineralogical characteristics of the lithologic material; but other factors such as vegetation may be more influential on pedogenic processes over a period of time (Maniyunda et al., 2014). Vegetation ages and forms differ in the ways in which they cause differences in soil properties and have a tremendous effect on the soil quality and general sustenance of soil resource (Onweremadu and Peter, 2016). Changes in the ecosystem can influence soil properties via the release of exudates, decay of plant parts as well as their rooting activities (Quideau et al., 2001). Biosequences are known to cause differences in soil morphology, biochemistry, and mineralogy (Quideau et al., 1996; Tice et al., 1996). Biosequences influence decomposition rates (Quideau et al., 2001) which depend on microbial activity (Vazquez et al., 2013) and surface residue characteristics (Abril et al., 2013). Plant species richness and nutrient recycling contribute to soil quality and its ecosystem functioning (Nielsen et al., 2011) due to varying transfer rates of litter fall components (Tate et al., 2011). Differences in soil properties and pedogenic characteristics among vegetal forms had been reported (Upadhaya et al., 2008; Onweremadu and Peter, 2016). Given that vegetation plays a substantial role in soil formation, it could be argued that some of the changes resulted from direct and indirect effects. When vegetation age and type create contrasting soil characteristics, it is assumed that they create pedogenic variations. Hence, the objective of this study was to investigate pedogenetic characteristics of soils located under a seven-year-old vegetation and a twenty-three-yearold vegetation in Ohaji-Egbema, Imo State Nigeria.

\section{MATERIALS AND METHODS}

Study Area

The study was carried out in Umuagwo, OhajiEgbema South-east Nigeria (latitude $5^{\circ} 15^{\prime} \mathrm{N}$ and longitude $6^{\circ} 58^{\prime} \mathrm{E}$ ) (Fig. 1). The soils were derived from coastal plain sands (Benin formation). OhajiEgbema situates in the humid tropics with a total 
mean annual rainfall of about $2500 \mathrm{~mm}$ and annual temperature range of $26-30^{\circ} \mathrm{C}$ (NIMET, 2014). Physiographically, the landscape of the area is a low-lying plain with almost no portion of the town exceeding $65 \mathrm{~m}$ above sea level. In both locations, the prevailing slope was gentle, averaging about $1 \%$. The original vegetation was rainforest which has been depleted by human activities, primarily agriculture and deforestation. The major socioeconomic activity of the area is farming. Soil fertility regeneration is by bush fallowing, while slash and burn is the major land clearing technique.

\section{Site Description}

Two different vegetation ages namely 7 and 23 years were investigated. The actual ages and land use history of the two varying land units were obtained from the information giving by the owners of the sites (farms). Both land units had similar land form (slope, 0.9-1.2 \%), different land use history and plant species. The 23-year-old vegetation contained mainly perennial plants such as oil palm (Elaeis guineensis), oil been tree (Pentaclethra macrophylla), bush mango (Irvingia gabonensis), Tithonia diversifolia. These plants among others form a thick and dense canopy which accommodates tremendous faunal activities. The 7year-old vegetation contained banana (Musa sapientum), grasses such as goat-weed (Sida acuta), elephant grass (Pennisetum purpurem), giant star grass (Cynodon plectostachyus), siam weed (Chromolaeana odorata), guinea grass (Panicum maximum) and wild legumes like pigeon pea (Cajanus cajan), Calapogonium mucunoid and was under continuous cultivation for three years before it was allowed to grow fallow. Generally, the 23-year-old vegetation had a much thicker and denser canopy than the 7-year-old vegetation.

\section{Field Studies and Laboratory Analysis}

The two vegetation ages were randomly selected. One profile pit was dug in each of the vegetation ages. Profile description and sampling were done according to the guidelines of FAO (2006). Delineation of horizon boundaries was accomplished before actual sample collection for laboratory analyses. Following the characterization and description of the profiles, the soils were classified in accordance with soil criteria outlined in Soil Survey Staff (2006). Taxonomic classification was done to the Subgroup level. The soil classes derived from soil taxonomic classification of the USDA were correlated to the World Reference Base. Macro-morphological properties of the various horizons were determined in the field and samples were collected based on horizon differentiation from the soil profile pits. Soil colour was determined using Munsell soil colour chart while other morphological properties (consistence, root composition, and structure) were determined by visual observation. Undisturbed core samples were collected for bulk density determination. The profile pits were geo-referenced using Handheld Global Positioning System (GPS) Receiver - Garmin Ltd Kansas, USA. Bulked soil samples collected were air-dried, gently crushed and passed through $2 \mathrm{~mm}$ sieve to obtain fine earth separates. The processed soil samples were analyzed for some Physico-chemical properties. Particle size distribution was carried out by hydrometer method (Gee and Or, 2002). Silt-clay ratio was calculated from silt and clay contents of the soils. Bulk density was determined using the procedure outlined by Arshad et al. (1996). The moisture content was determined gravimetrically. Soil $\mathrm{pH}$ was measured electrometrically by a glass electrode in $\mathrm{pH}$ meter in distilled water suspension using a soil: liquid ratio of 1: 2.5 (Thomas, 1996). Exchangeable bases ( $\mathrm{Ca}, \mathrm{Mg}, \mathrm{K}, \mathrm{Na}$ ) were extracted with neutral ammonium acetate (NH4OAc). Exchangeable calcium and magnesium were determined by ethylene diamine-tetraacetic acid (EDTA) titration method while exchangeable potassium and sodium were estimated by flame photometry (Jackson, 1962), the TEB was then derived from the summation of the exchangeable bases. Effective cation exchange capacity (ECEC) was the sum of the exchangeable bases and the exchangeable acidity. Soil organic carbon (SOC) was determined by Walkley and Black digestion method (Nelson and Sommers, 1982); organic matter was computed as organic carbon $\times 1.724$. Total nitrogen was estimated by micro-Kjeldahl digestion method (Bremner and Mulvaney, 1982) while available phosphorus was determined by Bray II Method (Olsen and Sommers, 1982). Clay argillation was calculated after Ahukaemere (2015):

$$
\frac{2 /(\mathrm{AB}+\mathrm{Bt} 1)}{\mathrm{AB}}=\geq 1
$$

where $A B$ is the clay content of the $A B$ horizon, and $\mathrm{Bt} 1$ is the clay content of the Bt1 horizon.

\section{Data Analysis}

Measured variables in the data set were analyzed using classical statistical methods to obtain the descriptive statistics. The vertical variation of soil properties were assessed by coefficient of variation (CV). The $\mathrm{CV}$ was ranked according to the procedure of Wilding (1985) whereby $\mathrm{CV} \leq 15 \%$ is low variation, CV $15-35 \%$ is moderate variation, and $\mathrm{CV}>35 \%$ is high variation.

\section{RESULTS AND DISCUSSION \\ Morphological Properties of Soils}

Table 1 shows the macro morphological properties of the studied soils. The soil profiles were deep as at the time of sampling with all pedons having the depth of $200 \mathrm{~cm}$. All the pedons were well drained which could be adduced to a low water table of the 
soils which could have enhanced infiltration, seepage, and percolation. There was no root or water restrictive layer within the profile depth in all the pedons. Soil colour ranged from dark reddish gray (7.5 YR 3/1 moist) to red (2.5 YR 5/8 moist) in 23-year-old vegetation and dark reddish brown (5 YR 2/3 moist) to yellowish red (5 YR 5/8 moist) in 7-year-old vegetation. Generally, soils were darker and browner at the epipedon and redder down the profile in all the pedons. The dark colour observed at the surface horizons is attributed to organic carbon contents of the horizons. The soils had mainly weak, very fine granular to moderate, medium blocky structure in the 23-year-old vegetation and weak, fine granular to moderate, very coarse blocky structure in the horizons of 7-year-old vegetation. Soils of the two contrasting vegetation ages had a very friable consistence that graduated into firm consistence in the lower horizons. The root composition of the soils showed the abundance of fine and medium roots at the surface horizons of all the profiles. No root was seen at the deepest horizons of these profiles. The 23-year-old vegetation contained coarser roots than the 7 -yearold vegetation, which could be due to the presence of trees - an important attribute of the forest. Also, the Oe (hemic) and Oa (sapric) horizons of the 23year-old vegetation (forest floor) (Fig. 2) contained dead and partially decomposed debris which is a reflection of high organic carbon recorded in these horizons. 23-year-old vegetation had the most extensive rooting system with roots penetrating down to $150 \mathrm{~cm}$ while 7-year-old vegetation had a rooting pattern much less extensive. The maximum rooting depth was about $31 \mathrm{~cm}$ (Table 1). Awotoye et al. (2011) reported the abundance of fibrous roots in $0-20 \mathrm{~cm}$ depth in a re-growth forest and this possibly enhances good biological and chemical characteristics of soils.

\section{Physical Properties of Soils}

The soil texture ranged from loamy sand to sand. The soils were preponderantly sand in most of the profiles (Table 2). However, sand accumulation was higher $(>80 \%)$ in the epipedon when compared to the subsurface horizons $(<70 \%)$. texture has earlier been defined as a near permanent attribute of the soil and hardily does it easily change due to vegetation age, land use, management or conservation. There was a high variation $(\mathrm{CV}>$ $35 \%$ ) of clay fractions of the soil matrix in all the pedons while little variation $(\mathrm{CV}<7 \%)$ was recorded in the distribution of sand down the profile. High variation in the clay fractions of the soils could be due to the existence of argillic horizons in the pedons; indicating wide variation in the clay contents of the horizons and increased clay down the soil profile. Soil properties manifest both long and short range variability and are multivariate in nature (Obi et al., 2010). This variability can be studied using $\mathrm{CV}$ in which case, ranking of $\mathrm{CV}$ of soil properties are grouped into different classes including least $(\leq 15 \%)$, moderately $(15 \leq 35 \%)$ and highly $(>35 \%)$ variable according to Wilding (1985). Obalum et al. (2013) reported variation among soil properties under contrasting vegetation types in three different locations in southeastern Nigeria using $\mathrm{CV}$. The range of the mean values of silt/clay ratio (SCR) of the soils was 0.73-0.91. The SCR is an important index used in the evaluation of clay migration, stage of weathering and age of parent material and soil (Nwaka, 1990; Yakubu and Ojanuga, 2006). The more highly weathered a soil is, the lower the silt fraction. FAO (1990) reported that SCR $<0.20$ indicates a low degree of weathering. Van Wambeke (1962) reported that old parent materials usually have a SCR below 0.15 while SCR above 0.15 is indicative of young parent materials.

However, results of this study showed that all the soils had SCR above 0.2 indicating the high degree of weathering. Generally, SCR of the soils decreased with profile depth (Table 2). The decreased in SCR values down the soil profile is an indication that subsoil horizons are more weathered than surface horizons. Nwokocha et al. (2003) reported that decreasing SCR down the pedon suggest increased weathering of silt to clay with depth. They further opined that this phenomenon in addition to illuviation explained the increase in clay with the depth of profiles. The soil bulk density increased down the natural horizons and showed values (mean, 1.34-1.53 $\mathrm{g} \mathrm{cm}^{-3}$ ) that would allow vigorous growth of plant roots and soil organisms. The variation in bulk density across the locations was low to moderate $(\mathrm{CV}=6.35 \%, 16.10 \%)$. Bulk density influences water availability and flow and the growth of plant roots. The results indicated that the soils had optimal values. Soil moisture content ranged from 8.03 to $11.85 \%$ (mean $=10.07$ ) in the 23-year-old vegetation and from 10.45 to 13.36 (mean $=12.18)$ in the 7-year-old vegetation. Generally, moisture content of the soils was low, showing that the soils are sandy and as such are not able to retain enough moisture.

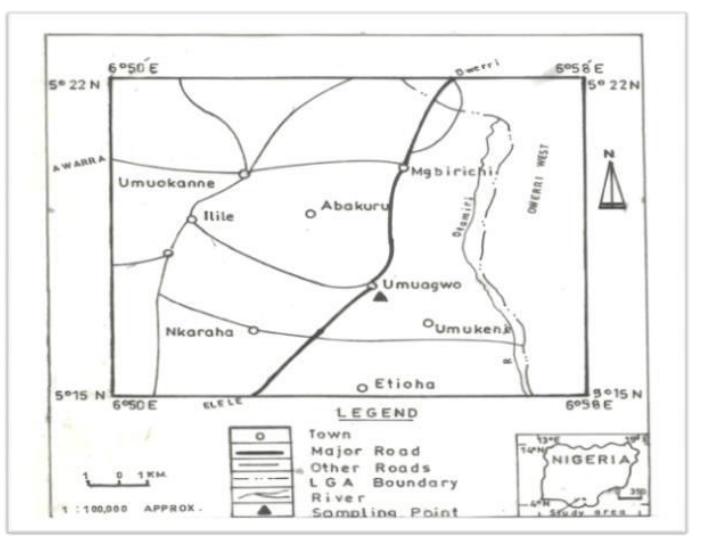

Fig. 1: Map of Ohaji-Egbema indicating the sampling sites (Umuagwo). Source: Geology Department, FUTO 
Table 1: Morphological properties of soil under different vegetation ages

\begin{tabular}{|c|c|c|c|c|c|c|}
\hline Depth $(\mathrm{cm})$ & Horizon & Soil colour (moist) & Soil structure & Consistence (moist) & Root composition & Tex. Class \\
\hline & \multicolumn{6}{|c|}{ 23-year-old vegetation } \\
\hline $0-4$ & $\mathrm{Oe}$ & $7.5 \mathrm{YR} 3 / 1$ & $1, \mathrm{v} \mathrm{f} \mathrm{gr}$. & Very friable & $\mathrm{Dpd}, 2 \mathrm{~m}$ & $\mathrm{LS}$ \\
\hline $4-18$ & $\mathrm{Oa}$ & $10 \mathrm{YR} 3 / 3$ & $2, \mathrm{v} f \mathrm{gr}$. & Very friable & $2 \mathrm{~m}$ & $\mathrm{LS}$ \\
\hline $18-48$ & A & $7.5 \mathrm{YR} 4 / 3$ & 2 , f gr. & Very friable & $1 \mathrm{~m}$ & LS \\
\hline $48-99$ & $\mathrm{AB}$ & $7.5 \mathrm{YR} 4 / 3$ & 2,me, sbk & Friable & $1 \mathrm{c}$ & SL \\
\hline $99-154$ & Bt1 & $7.5 \mathrm{YR} 5 / 8$ & $2, \mathrm{f}$ gr. & Friable & $1 \mathrm{c}$ & SL \\
\hline $154-200$ & $\mathrm{Bt} 2$ & $2.5 \mathrm{YR} 5 / 8$ & $\begin{array}{l}2, \text { me abk. } \\
7 \text {-year-olc }\end{array}$ & $\begin{array}{l}\text { Firm } \\
\text { egetation }\end{array}$ & No root & SL \\
\hline $0-11$ & A & $5 Y R 2 / 3$ & $2, \mathrm{f}$ gr. & Very friable & $2 \mathrm{f}$ & $\mathrm{LS}$ \\
\hline $11-31$ & $\mathrm{AB}$ & $5 \mathrm{YR} 4 / 2$ & $2, \mathrm{v} f \mathrm{gr}$. & Very friable & $2 \mathrm{f}$ & $\mathrm{S}$ \\
\hline $31-86$ & EB & $2.5 \mathrm{YR} 4 / 2$ & $2, \mathrm{me}$, sbk. & Friable & No root & LS \\
\hline $86-121$ & Bt1 & $2.5 \mathrm{YR} 4 / 8$ & $2, \mathrm{me}, \mathrm{sbk}$ & Firm & No root & $\mathrm{LS}$ \\
\hline $121-154$ & $\mathrm{Bt} 2$ & $2.5 \mathrm{YR} 4 / 8$ & 2, me, sbk & Firm & No root & $\mathrm{LS}$ \\
\hline $154-200$ & $\mathrm{Bt} 3$ & 5YR 5/8 & $2, \mathrm{v} \mathrm{c}$ abk & Firm & No root & $\mathrm{LS}$ \\
\hline
\end{tabular}

Horizon: Oe = Hemic horizon, Oa = Sapric, Textural Class: LS = Loamy sand, SL = Sandy loam, $\mathrm{s}=$ sand, Structure: $1=$ weak, $2=$ moderate, $\mathrm{me}=$ medium, $\mathrm{V}=$ very, $\mathrm{f}=$ fine, gr. = granular, sbk = sub-angular blocky, Root $:$ Dpd $=$ dead and partially decomposed debris, 1 = few, 2 = many, $m=$ medium, $f=$ fine, $c=$ coarse

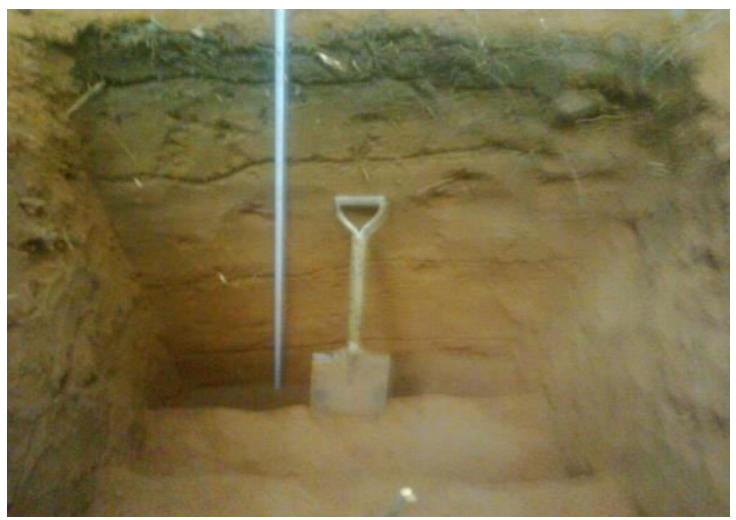

Fig. 2: Profile pit under the 23-year-old vegetation

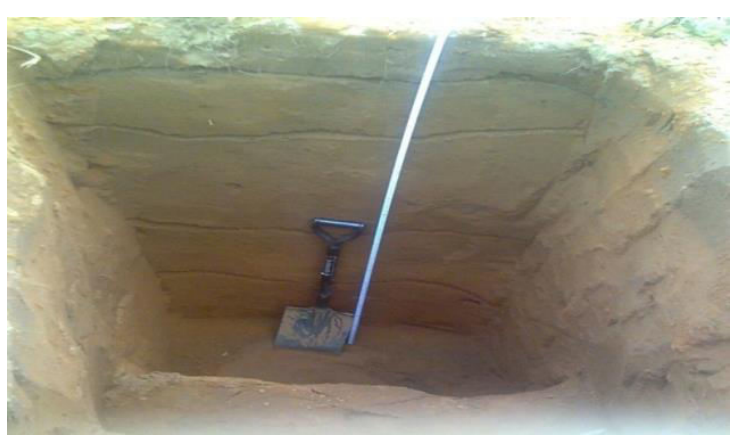

Fig. 3: Profile pit under the 7-year -old vegetation

\section{Chemical Properties of Soils}

Table 3 shows the chemical properties of the soils. Soils of the two contrasting vegetation ages were strongly acidic, due to more uptakes of basic cations by the plants. According to Offiong et al. (2009), differences in quantity and quality of biomass returned to the soil affect soil reaction. The SOC contents decreasing with depth indicates more pronounced activity of organisms in the upper horizon (Table 3). Generally, SOC contents of the $\mathrm{Oe}$ and $\mathrm{Oa}$ horizons of the 23-year-old vegetation were high due to high litter accumulation and less mineralization. Also, 23-year-old vegetation showed higher mean SOC than the 7-year-old vegetation. The ECEC of the soils was generally low. Soils of the coastal plain sands origin are often of low ECEC, base cations and base saturation (Lekwa and Whiteside, 1986; Ogban and Ekerette, 2001).

\section{Pedogenesis}

The soils formed under 23-year-old vegetation had $18 \mathrm{~cm}$ thick $\mathrm{O}$ horizon with distinct $\mathrm{Oe}$ and $\mathrm{Oa}$ components and $30 \mathrm{~cm} \mathrm{~A} \mathrm{horizon} \mathrm{(Table} \mathrm{1).}$ However, the O horizon was not found in the 7year-old vegetation. The thickness of A horizon under 7-year-old vegetation was $11 \mathrm{~cm}$. There was an outstanding littering pedogenic process in 23year-old vegetation leading to the formation of the $\mathrm{O}$ horizon. Also, at the epipedon of the two varying soil groups, there was evidence of melanization and this possibly entrained darker colouration on the surface horizons (Figs. 2 and 3). Melanization is a dominant process in grasslands and is favoured by the addition of a large amount of organic material into the soil by plants and animals (JohnsonMaynard et al., 2004). In both vegetation ages, clay increased with profile depth indicating clay argillation and formation of clay bulge. Argillation results indicated clay translocation at the depth of $48-200 \mathrm{~cm}$ in soils under 23-year-old vegetation and $86-200 \mathrm{~cm}$ under the 7-year-old vegetation. High argillation $(>1)$ recorded in these horizons indicated the presence of clay bulge, eluviation and illuviation processes in both soils. The lessivation process was also observed to have occurred in all the pedons with marked clay skin observed in the field and increased clay fraction down the pedon thereby giving rise to $\mathrm{Bt}$ (argillic) horizon. According to Philips (2004), vertical translocation of clay involves lessivage or argilluviation (physical washing of fine soil fraction from upper to lower layers), gravitational setting or solutionprecipitation by percolating water. The low exchangeable bases and predominance of low $\mathrm{pH}$ values observed in all the profiles were an indication of leaching process. Also, high organic carbon contents of the surface horizons under 23year-old vegetation was presumed to be a result of less mineralization and humification as conditioned by low radiation in the soil due to dense canopy. On the other hand, lower organic matter content of the soils of the 7-year-old vegetation was an indication of rapid mineralization processes occurring in these soils. 
Table 2: Physical properties of soil under different vegetation ages

\begin{tabular}{|c|c|c|c|c|c|c|c|}
\hline Depth $(\mathrm{cm})$ & Horizon & \multicolumn{3}{|c|}{$\left(\mathrm{g} \mathrm{kg}^{-1}\right)$} & SCR & $\begin{array}{c}\mathrm{BD} \\
\left(\mathrm{g} \mathrm{cm}^{-3}\right)\end{array}$ & $\begin{array}{l}\mathrm{MC} \\
(\%)\end{array}$ \\
\hline \multicolumn{8}{|c|}{ 23-year-old vegetation } \\
\hline $0-4$ & Oe & 858 & 94 & 48 & 1.96 & 1.10 & 11.85 \\
\hline $4-18$ & $\mathrm{Oa}$ & 858 & 64 & 78 & 0.82 & 1.06 & 8.03 \\
\hline $18-48$ & A & 818 & 74 & 108 & 0.69 & 1.36 & 10.83 \\
\hline $48-99$ & $\mathrm{AB}$ & 778 & 54 & 168 & 0.32 & 1.38 & 9.34 \\
\hline $99-154$ & Bt1 & 758 & 54 & 188 & 0.29 & 1.53 & 10.08 \\
\hline $154-200$ & $\mathrm{Bt} 2$ & 748 & 54 & 198 & 0.27 & 1.58 & 10.26 \\
\hline Mean & & 80300 & 65.66 & 131.00 & 0.73 & 1.34 & 10.07 \\
\hline $\mathrm{CV}(\%)$ & & 6.10 & 24.24 & 47.3 & 87.0 & 16.10 & 12.91 \\
\hline \multicolumn{8}{|c|}{ 7-year-old vegetation } \\
\hline $0-11$ & A & 878 & 64 & 58 & 1.10 & 1.44 & 12.71 \\
\hline $11-31$ & $\mathrm{AB}$ & 898 & 54 & 48 & 1.13 & 1.43 & 10.45 \\
\hline $31-86$ & EB & 858 & 94 & 48 & 1.96 & 1.44 & 11.20 \\
\hline $86-121$ & Bt1 & 838 & 64 & 98 & 0.65 & 1.61 & 12.31 \\
\hline $121-154$ & $\mathrm{Bt} 2$ & 818 & 54 & 128 & 0.42 & 1.61 & 12.55 \\
\hline $154-200$ & Bt3 & 818 & 34 & 148 & 0.23 & 1.62 & 13.36 \\
\hline Mean & 851.30 & 60.67 & 88.00 & 0.91 & 1.53 & 12.10 & \\
\hline
\end{tabular}

Table 3: Chemical properties of soil under different vegetation ages

\begin{tabular}{|c|c|c|c|c|c|c|c|c|}
\hline Depth (cm) & Horizon & $\mathrm{pH}$ (water) & $\begin{array}{c}\mathrm{AvP} \\
\left(\mathrm{mg} \mathrm{kg}^{-1}\right)\end{array}$ & TEB $\left(\mathrm{cmol} . \mathrm{kg}^{-1}\right)$ & $\begin{array}{c}\text { ECEC } \\
\left(\mathrm{cmol}_{+} \mathrm{kg}^{-1}\right)\end{array}$ & BS (\%) & $\begin{array}{c}\mathrm{SOC} \\
\left(\mathrm{g} \mathrm{kg}^{-1}\right)\end{array}$ & $\begin{array}{c}\mathrm{TN} \\
\left(\mathrm{mg} \mathrm{kg}^{-1}\right)\end{array}$ \\
\hline \multicolumn{9}{|c|}{ 23-year-old vegetation } \\
\hline $0-4$ & Oe & 5.01 & 28.13 & 9.03 & 10.65 & 84.79 & 42.00 & 12.00 \\
\hline $4-18$ & $\mathrm{Oa}$ & 4.78 & 26.8 & 7.63 & 9.71 & 78.58 & 16.63 & 4.00 \\
\hline $18-48$ & A & 4.35 & 20.00 & 4.55 & 6.31 & 72.11 & 8.11 & 1.00 \\
\hline $48-99$ & $\mathrm{AB}$ & 4.20 & 16.10 & 4.58 & 5.94 & 77.1 & 6.90 & 2.00 \\
\hline $99-154$ & Bt1 & 4.20 & 20.00 & 4.63 & 6.24 & 74.20 & 6.10 & 2.00 \\
\hline $154-200$ & Bt2 & 4.80 & 17.80 & 4.21 & 5.49 & 76.69 & 7.21 & 2.10 \\
\hline Mean & & 4.56 & 21.47 & 5.77 & 7.39 & 77.25 & 14.49 & 3.85 \\
\hline$C V$ & & 8.00 & 23.00 & 35.0 & 30.00 & 5.63 & 96.75 & - \\
\hline \multicolumn{9}{|c|}{ 7-year-old vegetation } \\
\hline $0-11$ & A & 4.17 & 18.1 & 5.84 & 7.76 & 75.26 & 15.91 & 12.00 \\
\hline $11-31$ & $\mathrm{AB}$ & 4.45 & 17.8 & 6.17 & 7.96 & 77.51 & 11.12 & 12.10 \\
\hline $31-86$ & EB & 6.03 & 16.1 & 7.07 & 9.04 & 78.21 & 8.10 & 8.20 \\
\hline $86-121$ & Bt1 & 5.30 & 17.1 & 4.61 & 5.65 & 81.59 & 7.00 & 8.20 \\
\hline $121-154$ & Bt2 & 5.02 & 17.5 & 6.18 & 8.02 & 77.06 & 5.44 & 0.60 \\
\hline $154-200$ & $\mathrm{Bt} 3$ & 5.11 & 18.34 & 7.57 & 9.12 & 83.00 & 5.10 & 6.00 \\
\hline Mean & & 5.01 & 17.49 & 6.24 & 7.93 & 78.77 & 8.78 & 7.85 \\
\hline$C V$ & & 13.0 & 46.00 & 17.0 & 16.11 & 37.21 & 46.87 & 54.49 \\
\hline
\end{tabular}

Table 4: Classification of soils under different vegetation ages

\begin{tabular}{llllll}
\hline Vegetation age & Soil Order & Sub-order & Great group & USDA Subgroup & WRB \\
\hline 23-year-old vegetation & Alfisols & Udalfs & Paleudalfs & Arenic Paleudalfs & Chromic Lixisols \\
7-year-old vegetation & Alfisols & Udalfs & Hapludalfs & Arenic Hapludalfs & Arenic Lixisols \\
\hline
\end{tabular}

\section{Soil Classification}

Soils of the studied pedons had greater clay contents in the Bt horizons indicating eluviation and illuviation pedogenetic processes, base saturation (ECEC at $1 \mathrm{~N} \mathrm{NH}_{4} \mathrm{OAc} \mathrm{pH} 7$ ) greater than 35 percent at the $140 \mathrm{~cm}$ depth below the mineral soil surface. As a result, the soils can be classified as Alfisols (Table 4). This was because the soils satisfied all the conditions as stated above and in soil taxonomy (Soil Survey Staff, 2006). Because all soils under the two vegetation ages were well drained and had udic soil moisture regime, they could be classified under the suborder Udalfs. At the great group level, soils under 23year-old vegetation were classified as Paleudalfs due to the presence of well developed argillic horizons, $3 \%$ or more clay depletion from the eluvial horizon with munsell hue of 7.5 YR or redder, chroma (moist) of 5 or more at the depth of $100 \mathrm{~cm}$. Soils under 7-year-old vegetation were classified as Hapludalfs; because of the possession of no special diagnostic feature at the great group level thus making them a typical of all other great groups under the suborder Udalf. The two pedons were classified at subgroup level as Arenic Paleudalf and Arenic Hapludalf due to the presence of sandy particle size class throughout a layer extending from the mineral soil surface to the top of an argillic horizon at a depth of 50-200 cm. (Table 2). 


\section{CONCLUSIONS}

The study revealed that major pedogenic processes in the two soil groups were littering, mineralization, humification, melanization, leaching, illuviation, and eluviation. There was an outstanding littering pedogenic process in 23-year-old vegetation leading to the formation of the $\mathrm{O}$ horizon. However, the $\mathrm{O}$ horizon was not found in the 7-year-old vegetation. Also, at the epipedon of the two varying soil groups, there was evidence of melanization and this possibly entrained darker colouration on the surface horizons. In both vegetation ages, clay increased with profile depth indicating clay argillation and formation of clay bulge. Generally, Soil properties differed in the soils of the two contrasting vegetation ages and these affected the degree of pedogenesis in the soils.

\section{REFERENCES}

Abril, A.C., Merlo, C and Noe, L. (2013). Realistic soil carbon sink estimate in dry forest of western argentina based on humic substance content. Journal of Arid Environment, 91, 113-118

Ahukaemere, C.M. (2015). Sequestration and Dynamics of Carbon and Nitrogen in Soils of Dissimilar Lithologies under Different Land Use Types in South-east Nigeria. PhD Thesis, Department of Soil Science and Technology, Federal University of Technology, Owerri Nigeria. 266 pp

Arshad, M.A., Lowery, B., and Grossman, B. (1996) Physical tests for monitoring soil quality. pp. 123142. In: J.W. Doran and A.J. Jones (eds.) Methods for Assessing Soil Quality. Soil Science Society of America Special Publication 49. SSSA, Madison, WI

Awotoye O.O., Ogunkunle, C.O. and Adeniyi S.A. (2011). Asssessment of soil quality under various land use practices in a humid agro-ecological zone of Nigeria. African Journal of Plant Science 5(10), 565-569

Bremner, J.M., and Mulvaney, G.S. (1982). Nitrogen total. In: A.L. Page, R.H. Miller and D.R. Keeney, (eds.) Methods of Soil Analysis. Part 2. American Society of Agronomy, No, 9, Madison, WIS pp. 595-624

FAO (Food and Agricultural Organization) (1990). Soil Map of the World. Revised Legend, World Soil Resources Report, FAO Rome

FAO (Food and Agricultural Organization) (2006). World Reference Base for Soil Resources 84. World Soil Resources Report, ISSS-AISSIBG, FAO Rome, Italy

Gee, G.W. and Or, D. (2002). Particle size analysis. In: J.H. Dane and G.C. Topp (eds). Methods of soil Analysis, Part 4, Physical Methods. Soil Science Society of America. Book series . No. 5 ASA and SSA Madison, W1, pp 255-293

Jackson, M.L. (1962). Soil Chemical Analysis. New York: Prentice-Hall Inc. 498 pp

Johnson-Maynard, J.L., Shouse, P.J., Graham, R.C., Castigilione, $\mathrm{P}$ and Quideau, S.A. (2004). Microclimate and pedogenic implications in a 50year old chaparral and pine biosequence. Soil Science Society of American Journal, 68, 876-884
Lekwa, G. and Whiteside, E.P. (1986). Coastal plain soils of southeastern Nigeria: I. morphology, classification and genetic relationships. Soil Science Society of American Journal, 50, 154-160

Maniyunda, L.M., B.A. Raji, A.C. Odunze and W.B. Malgwi, (2014). Geochemistry of major elemental oxides on a lithosequence in Kaduna State Nigeria. Nigeria Journal of Soil Science, 24, 24-35

Nelson, D.W. and Sommers, L.E. (1982). Total carbon, organic carbon and organic matter. In: A.L. Page, R.H. Miller and D.R. Keeney (eds.) Methods of Soil Analysis (Part 2). American Society of Agronomy. Madison, WIS. pp. 539-599

Nielsen, U.N., Ayres, E., Wall, D.H. and Bardgett, R.D (2011). Soil biodiversity and carbon cycling :a review and synthesis of studies examining diversityfunction relationship. European Journal of Soil Science, 62, 105-116

NIMET (Nigerian Meteorological Agency), Nigeria, (2014). Climate Weather and Water Information, for Sustainable Development and Safety

Nwaka, G.I.C. (1990). Studies on dune soils of Borno State. morphology, classification and physical properties. Annals of Borno, 6 (7), 198-204

Nwokocha, C.C., Akamigbo, F.O.R. and Chukwu, G.O. (2003). Characterization and evaluation of soils of Umuahia North Local Government Area of Abia State for agricultural production. In: Ojeniyi et al., (eds.). Land Degradation, Agricultural Productivity and Rural Poverty: Environmental Implications. Proceedings of the $28^{\text {th }}$ Annual Conference of the Soil Science Society of Nigeria. 308-315

Obalum, S.E., Oppong, J., Igwe, C,A., Watanabe, Y. and Obi, M.E. (2013). Spatial variability of uncultivated soils in derived savanna. International Agrophysics, 27, 57-67

Obi, J.C., Awonuga, A.O., and Umeojiakor, A.O. (2010). Spatial dependence of some physical properties of a Typic Plithaqualf on the basement complex in Southweastern Nigeria. Agro-Science, 9 (1), 38-46

Offiong, R.A., Atu, J.E., Njar, G.N. and Iwara, A.I. (2009). Effects of land use change on soil physicochemical properties in South-south Nigeria. African Journal of Environment, Pollution and Health, 7 (2), 47-51

Ogban, P.I. and Ekerette, I.O. (2001). Physical and chemical properties of the coastal plain sands soils of South-east Nigeria. Nigerian Journal of Soil and Environmental Res., 2, 6-14

Olsen, S.R. and Somers, L.E. (1982). Phosphorus. In: A.L. Page, R.H. Miller and D.R. Keeney (eds.) Methods of Soil Analysis (Part 2). American Society of Agronomy, Madison WIS, pp. 403-430

Onweremadu, E.U., and Peter, K.D. (2016). Pedogenesis of soils of two tropical microclimates in Owerri area South-east Nigeria. International Journal of Soil Science, 11(1), 14-18

Philips J.D. (2004). Geogenesis, pedogenesis, and multiple causality in the formation of texturecontrast soils. Catena, 58, 275-295

Quideau, S.A., Chadwick, O.A., Graham, R.C and Wood, H.B. (1996). Base cation biogeochemistry and weathering under oak and pine. A controlled long-term experiment. Biogeochemistry, 35, 377398 
Quideau, S.A., Chadwick, O.A., Trumbore, S.E., Johnson-Maynard, J.L Graham, R.C and Anderson, M.A. (2001). Vegetation control on soil organic matter dynamics. Organic Geochemistry, 32, 247252

Tate, K.R., Lambie, S.M., Ross, D.J. and Dando, J. (2011). Carbon transfer from ${ }^{14} \mathrm{C}$-labeled needles to mineral soil and ${ }^{14} \mathrm{C}-\mathrm{CO}_{2}$ production in a young Pinus radiata Don stand. European Journal of Soil Science, 62, 127-133

Tice, K.R., Graham, R.C. and Wood, H.B. (1996). Transformation of 2:1 phyllosilicates in 41-year old soils under oak and pine. Deoderama, 70, 49-62

Thomas, G.W., (1996). Soil pH and soil acidity. In: L.D. Sparks (ed.), Methods of Soil Analysis, Part 3, Chemical Methods). SSSA Book Series. No. 5

Upadhaya, K., Pandey, H.N., Barik, S.K and Tripathi, R.S. ( 2008). Organic matter, $\mathrm{N}$ and $\mathrm{P}$ dynamics of fine and coarse roots in a humid subtropical forest ecosystem exposed to disturbance in Meghalaya, Northeast India. Malaysian Journal of Soil Science, $12,45-60$
Van Wambeke, A.R. (1962). Criteria for classifying tropical soils by age. Journal of Soil Science, 13, $124-132$

Vazquez, C. Merlo, C., Neo, L., Romero, C. and Abril, A. (2013). Sustainability/resilience of soil organic matter components in Argentinean Arid Region. Spanish Journal of Soil Science, 3, 73-77

Wilding, L.P. (1985). Spatial Variability: Its Documentation, Accommodation, and Implication to Soil Surveys. In: Nielsen, D.R. and Bouma, J. (eds.), Soil Spatial Variability. Pudoc. Wageningen, The Netherlands, pp. 166-194

Soil Survey Staff. (2006). Soil Taxonomy. A Basic System of Soil Classification for Making and Interpreting Soil Surveys. $10^{\text {th }}$ Edition. USDA Agricultural Handbook No. 436

Yakubu, M. and Ojanuga, A.G. (2013). Pedogenesis, weathering status and mineralogy of the soils on ironstone plateaux (laterites), Sokoto Nigeria. Bayero Journal of Pure and Applied Science, 6(2), 93-100 